\title{
Synopsis of Part II: The Scenes
}

1 Departure from the Cape (1835-37)

2 Presentation of the Bible to Jacobus Uys (April 1837)

3 Trichardt at Soutpansberg (summer 1836 to autumn 1837)

4 Trichardt in Delagoa Bay (April 1838)

5 The Battle of Vegkop (October 1836)

6 Inauguration of Retief as governor (6 and 11 June 1837)

7 The Battle of Kapain (28-30 November 1837)

8 Negotiation with Moroka (October/November 1836)

9 Report from Retief at Blydevooruitsig (11 November 1837)

10 Debora Retief records her father's birthday (12 November 1837)

11 Descent from the Drakensberg (late 1837)

12 The Treaty with Dingane (4 or 6 February 1838)

13 Murder of Retief and his men (6 February 1838)

14 Massacre of women and children at Bloukrans (16/17 February 1838)

15 Teresa Viglione warns camps around Bloukrans (17 February 1838)

16 Dirkie Uys defends his father (11 April 1838)

17 Marthinus Oosthuizen gallops through Zulu lines (17 February 1838)

18 Women spur men on (after 17 February 1838)

19 Arrival of Andries Pretorius (22 November 1838)

20 The Vow (9 December)

21 The Battle of Blood River (16 December 1838)

22 Building the Church of the Vow (1840-43)

23 Women at Saailaer (1838?)

24 Mpande proclaimed king of the Zulu (10 February 1840)

25 Death of Dingane (February 1840)

26 Return from Natal over the Drakensberg (after 1843)

27 Sand River Convention (17 January 1852) 
